\title{
L2 Communication Apprehension Anxiety: Investigating the Underlying Causes in the Iranian EFL Classroom
}

\author{
Ms.Naeimeh Mojerloo \\ Shahid Beheshti University
}

\begin{abstract}
Horwitz (1986) highlighted foreign language classroom anxiety as one of the crucial factors affecting the process of foreign language learning. Since its introduction by Horwitz (1986), foreign language classroom anxiety has been the focus of a plethora of studies in the field of L2 acquisition. The present study aims to investigate the sources of speaking anxiety that English as a foreign language (EFL) adult Iranian learners may experience in the classroom environment. To this end, Horwitz`s (1986) Foreign Language Classroom Anxiety Scale (FLCAS) was administered to 180 adult Iranian male and female EFL learners. The data obtained from the questionnaire was analyzed and the respondents who scored the highest on the communication apprehension section of the questionnaire were considered as the most anxious learners while speaking English in the classroom. Subsequently, an interview was conducted with a subsample of the most anxious participants to find out what the sources of their anxiety were. Based on the themes emerged from the interview, four factors were found to underpin the anxiety learners may feel while communicating in English in the classroom context. In the order of importance, they included: teacher, English language, making mistakes, and classmates. The implications of the findings for $L 2$ teachers and the avenues for future research are discussed.
\end{abstract}

Keywords: EFL learners; Foreign Language Classroom Anxiety; L2 acquisition; learning anxiety

\section{Introduction}

The role of affective variables in second and foreign language learning has been examined by researchers in the field for more than twenty years (from Tarampi, Lambert, and Tucker, 1968 to Horwitz and Young, 1991). One of these affective constructs which has been the focus of research for many years is Anxiety. In an EFL context, learners often experience a sense of distress, nervousness, 
and anxiety regardless of their level of proficiency. This feeling of tension is specifically obvious in speaking situations. Thus, learners and even the teachers sometimes wonder where this anxiety comes from and what the source is. Gregersen (2003) claimed Foreign language anxiety (FLA) is one of the major factors influencing the success of foreign language learning. Horwitz (1986) advanced the theory of Foreign Language Classroom Anxiety known as (FLACA) "a distinct complex of selfperceptions, beliefs, feelings, and behaviors related to classroom language learning arising from the uniqueness of the (foreign) language learning process" (Horwitz et al., 1986, p. 128.) FLA in his theory was composed of three different elements as 1 . Communication apprehension, which was defined as learners' inability to adequately express their thoughts and ideas. 2. Fear of negative social evaluation, which emerged from a learner's desire to leave a positive social impression on others. 3 . Test anxiety, an apprehension referring to academic evaluation. In communication apprehension, foreign language learners have trouble both in speaking and comprehending messages from others (Horwitz et al., 1986). MacIntyre and Gardner (1991) stated that Fear of negative evaluation is closely related to communication apprehension. Horwitz et al. (1986) assessed that almost one-third of foreign language learners experience language anxiety. As a result, he asserted that finding the sources of foreign language anxiety can help both teachers and the learners to cope with this affective variable. As the causes and sources of Foreign language anxiety can be different based on individuals and their learning context, this study aims to explore the probable sources of Iranian EFL learners' anxiety.

\section{Literature Review}

Since its initiation by McCroskey, communication apprehension (CA) has got broad investigate consideration. Embarking in the United States, the focus of CA was mostly on the First language, but later researchers found a connection between CA and foreign language. The significant role of CA in foreign language anxiety cannot be ignored as it is one of the central frameworks in the concept of FLA introduced by Horwitz et al. (1986). McCroskey and Richmond (1995) categorized CA into four different components: trait-like, context-based, audience-based and situational CA. Trait-like CA is a personality characteristic like variables but resistant to change. They defined context-based CA as "a relatively enduring, personality-type orientation toward communication in a given type of context" McCroskey and Richmond (1995). They found out that these two first components are highly correlated in a way that the higher is one's trait CA, the more anxiety one will experience in a specific situation. The next component which was audience-based CA stated that level of tension will be more subjected to the person present in the environment. As in language learning environment, it can be seen as a teacher or other students' presence in the classroom can cause apprehension. In McCroskey and Richmond's (1995) word audience-based CA is "a relatively enduring orientation toward communication with a given person or group of people". And the final component is situational CA "a transitory orientation toward communication with a given person or group of people" (McCroskey 
International Conference on Research in

Humanities and Social Sciences

Serbia | Belgrade | December 15-17, 2018

and Richmond, 1995) as it is evident the four components of CA can be categorized form the most trait-like CA and the most state-like CA.

Many believed that anxiety was one of the effective factors that seem to play a crucial role in foreign language learning (e.g. Dordinejad et.al, 2011; Horwitz, 2001; Maclntyre \& Gardner, 1989). Due to its importance in a learning context, many researchers provided a different definition of anxiety. Spielberger (1983, p. 1) defined anxiety as "the subjective feeling of tension, apprehension, nervousness and worry which is associated with an arousal of the automatic nervous system" and distinguished between two categories of anxiety: trait anxiety and state anxiety. He defined the former as a stable personality characteristic. Scovel (1978) also defined trait anxiety as a more permanent predisposition to be anxious. By contrast, state anxiety is seen as a reaction to anxietyprovoking stimuli like public speaking, examination, or class (Spielberger, 1983). Maclntyre and Gardner (1989) defined anxiety in relation to educational settings as an effective state which influences three stages of the learning process, namely input, processing, and output.

Besides, Alpert and Haber (1960, cited in Ellis 2008) distinguished between facilitating and debilitating anxiety. The former has a positive effect on the learning process because it motivates the learner to invest more time and energy on a task and thereby overcome their feelings of anxiety. However, the latter has a negative effect on learning and results in the learner's poor performance and inability to exploit his full capacities. Some researchers asserted that there might be some level of two anxieties present at the same time (Dewaele, 2002; Ellis 2008; Scovel, 1978). In other words, these two types of anxiety may function together in an individual (Scovel, 1978). More recently, Horwitz (2001) introduced Foreign Language Anxiety (FLA) as a type of state anxiety which is specific to foreign language learning situations.

A large number of studies have to date investigated the potential effect of foreign language anxiety on the L2 learning process (see, e.g., Horwitz, 2001; Saito \& Samimy, 1996; Sellers, 2000; Elkhafaifi, 2005; Zheng, 2008). Another line of L2 anxiety research has focused on various factors which can decrease or increase learners' language learning anxiety (e.g. Dordinejad et.al, 2011; Horwitz, 2001; Krementizer, 2005; MacIntyre \& Gardner, 1989). Moreover, several studies have identified speaking as the source of highest level of stress in the EFL classroom (Horwitz, 2010; Baran-Łucarz, 2011; Phillips, 1992; Price, 1991). This may be in large part due to the fact that speaking is the most conspicuous manifestation of L2 ability based on which one's L2 competence is judged (Lev-Ari \& Keysar, 2010). It can also be related to the nature of speaking which, as argued by Bygate (2009), makes it difficult for learners "to separate the business of coming to grips with the oral use of language from the issues of identity, face and human relationships (p. 401)".

As noted by Alrabai (2015), FLA is mainly a psychological factor rather than a linguistic one. He argues that FLA roots in the learner's perception of himself/herself which is the result of the interplay among a plethora of factors including self-perceptions, perceptions of others, and perceptions of FL learning. Onwugbuie et al. (1999) showed empirically that three aspects of self-perception, namely expectation of overall achievement in foreign language courses, perceived self-worth, and perceived scholastic competence, were significant predictors of foreign language anxiety. Following this, it can 
International Conference on Research in

Humanities and Social Sciences

Serbia | Belgrade | December 15-17, 2018

be concluded that the anxiety foreign language learners may experience while communicating through English in the classroom context is not merely associated with their L2 proficiency level. Rather, it is also liable to non-linguistic factors in the classroom context, too. A cursory look at the extant literature, however, shows that few if any studies have investigated the potential sources of L2 communication apprehension in the foreign language classroom context.

\section{Sources and causes of foreign language anxiety}

Due to its prevalence and negative effects on L2 learning, L2 teachers and researchers need to know the likely causes or sources of FLA so as to help alleviate foreign language learners' anxiety. Studies on FLA have highlighted different factors underlying foreign language learners' anxiety including situational variables like the content of the course or type of activities (Price, 1991; Tallon, 2006), instructors' behavior (Oh, 1992; Oxford, 1999a; Powell, 1991; Samimy, 1989; Spielmann and Radnofsky, 2001; Yan \& Horwitz, 2008; Young, 1991). Some other talk about learners' variable which may be a stimulus for foreign language learning anxiety (e.g., Bailey, Daley, \& Onwuegbuzie, 1999; Campbell, 1999; Dewaele, 2002; Gardner, Day \& Maclntyre, 1992; Gregersen \& Horwitz, 2002). The learner variable includes age, gender, and their learning style.

Horwitz et al. (1986), for example, found that learners' difficulty presenting their identity in the L2 is one of the major reasons for FLA. Sparks and Ganschow (1991, 1993a, 1993b) claim that poor language learning ability is the only reason for the anxiety that learners may experience in the foreign language learning process. In another study, Maclntyre and Gardner (1993) reported that FLA stemmed from repeated unpleasant experiences related to the foreign language. Based on a close review of the studies on the probable reasons underlying FLA, Young (1991) proposed six potential sources of language anxiety: (1) personal and interpersonal anxieties, (2) learner beliefs about language learning, (3) instructor beliefs about language teaching, (4) instructor-learner interactions, (5) classroom procedures, and (6) language testing. Young $(1994,1999)$ then categorized sources of FLA into three general groups, those stemming from the learner, the teacher, and the instructional practice.

In another study, Luo (2012) proposed a four-dimensional model of the sources of FLA. She argued that FLA roots from four main sources including the classroom environment, learner characteristics, the target language, and the foreign language learning process itself. She further noted that the anxiety foreign language learners experience is underpinned to a large degree by the classroom environment.

In a study done by Zhang and Zhong (2012), the possible causes of foreign language learning anxiety have been defined as "learner induced, classroom-related, skill-specific, and some society-imposed depending on different contexts". They believed that as learners are exposed to the high standard native version of English in their classroom they are subject to set unrealistic standards of their language learning which may lead to anxiety. 
International Conference on Research in

Humanities and Social Sciences

Serbia | Belgrade | December 15-17, 2018

Rajanthran et al. (2013) have also mentioned that the fear of falling short of these standards can hinder the learning process. Based on Young (1991) Anxious learners perceive their speaking ability as the most important skill so they always compare themselves with that of their peers and they think they are weaker than other language learners. Additionally, Kitano (2001) also claims that "speaking skill is usually the first thing that learners compare with that of peers, teachers and native speakers". Classroom-related anxiety can be associated with whatever and whomever available in learning context like; instructors, peers and classroom practices (Zhang and Zhong, 2012). In case of Instructors, if only they play a role of someone who corrects students constantly, who feels that learners lack of proficiency is something related to talent and gift may be contributing to learner language anxiety (Young, 1991). According to Hashemi and Abbasi (2013), an informal language classroom environment may probably be an astute solution to diminish the chance of anxiety provoking language learning context. In their words "formal language classroom setting is a major source of stress and anxiety because of its demand to be more correct and clearer in using the target language".

McCroskey in his study stated that language learning classroom is considered as a highly formalized zone in which there are many rules and instructions defining the acceptable behavior which may potentially provoke CA (McCroskey 1983).

By the formality, he specifically believed in the authority figure of the instructor which results in a pattern of interaction where one side is in power. This is what aggravates the apprehension problem (McCroskey 1983). Furthermore, the evaluation or criticisms coming from peers has also been reported as a major cause of anxiety (Conway, 2007).

Recently Korpela (2011) listed the causes of anxiety into two categories of internal and external. As the most worth mentioning internal causes of CA listed in her study learners low self-assessed level of English proficiency, unrealistic self- expectations, self-criticism level upon the error, the evaluation is done by others can be pointed. On the other hand, in her external list, CA was caused by lack of real and authentic practice, demotivating teachers and, high expectations imposed by teachers, lack of same level proficient student in a conversational group and the large proportion of people present in a learning context.

Some FLA research (e.g., Oxford, 2005) has also stated that causes of anxiety-related behavior can be different in different cultures. In case of Iranian language learners, culture differences can arouse an interest in examining FLA for multiple reasons. Considering the external causes of anxiety mentioned earlier in literature, Iranian learners may be subject to anxiety-provoking behaviors when they tend to speak in front of some of their opposite-sex peers in English classes since the educational system in Iran is segregated at all levels in their school times.

Based on the above review of the literature, the present study is an attempt to unravel the sources of $L 2$ communication apprehension in the Iranian EFL classrooms. In other words, this study aims to explore the possible sources of learners' anxiety which not only gives both teachers and learners right perspective on dealing with this variable but also might lead to a growing body of anxiety-related research. 


\section{Method}

\section{Participants}

Participants of the current study comprised 189 EFL learners ( 108 females and 81 males) who were recruited from two private language teaching institutes in Tehran and Arak. Students from the intermediate level were only invited to participate in the study to prevent any intervening effect that learners' level of proficiency can have on their speaking anxiety. They ranged in age from 16-37 $(M=24.46, S D=4.54)$.

\section{Research question}

The present study is guided by the following research question:

What are the Iranian EFL learners 'perceptions of the likely factors underpinning L2 communication apprehension?

It needs to be noted that no hypothesis was formulated for this research question given that it is a qualitative question.

\section{Instrument}

\subsection{Foreign Language Classroom Anxiety Scale (FLCAS)}

The anxiety level of students was measured by Horwitz, Horwitz, and Cope's (1986) Foreign Language Classroom Anxiety Scale (FLCAS) (see Appendix A). The FLCAS consists of 33 items and uses a 5-point Likert scale ("strongly disagree" to "strongly agree" with a neutral category in the middle). It measures three dimensions of classroom anxiety including; communication apprehension, test anxiety, and the fear of negative evaluation.

Possible scores on the FLCAS range from 33 to 165 . The higher the score, the higher the level of foreign language anxiety experienced by the learners. In his original study, Horwitz et al. (1986) reported a Cronbach's alpha of $0.93(\mathrm{~N}=108)$ and a test-retest correlation of $.83(\mathrm{~N}=78)$. The reliability of the questionnaire in the present study was .75. It needs to be noted that students completed the Persian version of the questionnaire to prevent any negative effect of participants' English proficiency on their responses. The translated version of FLCAS (see Appendix B) was taken from Atef-Vahid and Kashani (2011). They employed back-translation method to assure the validity of the questionnaire. 
International Conference on Research in

Humanities and Social Sciences

Serbia | Belgrade | December 15-17, 2018

\begin{tabular}{lccc}
$\mathbf{3}$ & Male & 147 & 17 \\
$\mathbf{4}$ & Male & 144 & 33 \\
$\mathbf{5}$ & Male & 143 & 22 \\
$\mathbf{6}$ & Male & 142 & 27 \\
$\mathbf{7}$ & Female & 141 & 22 \\
$\mathbf{8}$ & Female & 140 & 22 \\
$\mathbf{9}$ & Female & 139 & 24 \\
$\mathbf{1 0}$ & Female & 138 & 23 \\
$\mathbf{1 1}$ & Female & 136 & 19 \\
$\mathbf{1 2}$ & Male & 132 & 24 \\
$\mathbf{1 3}$ & Female & 130 & 26 \\
$\mathbf{1 4}$ & Male & 129 & 33 \\
$\mathbf{1 5}$ & Male & 128 & 23 \\
$\mathbf{1 6}$ & Male & 127 & 18 \\
$\mathbf{1 7}$ & Female & 126 & 27 \\
$\mathbf{1 8}$ & Female & 125 & 21 \\
$\mathbf{1 9}$ & Female & 124 & 22 \\
$\mathbf{2 0}$ & Female & 123 & 18 \\
\hline
\end{tabular}

\section{Data analysis:}

Data analysis included both quantitative and qualitative analysis. Quantitative analysis included calculating descriptive statistics for the communication apprehension subscale of the questionnaire. As for the qualitative analysis, learners responses to the interviews were transcribed verbatim and were analyzed for the recurrent themes. Table 4.1 presents descriptive statistics for the speaking anxiety subscale of the FLCAS ( $M=32.30$, $S D=11.771)$. In order to identify participants who scored very high or very low on the FLCAS, they were rank-ordered based on their scores on the communication apprehension subscale. Subsequently, $10 \%$ of participants who scored the highest on this subscale were selected. There were 20 learners ( 9 male, 11 female) who ranged in age from 18 to 33 years old. 
Table 6.1. Descriptive statistics of the FLCAS and its subscales

\begin{tabular}{|c|c|c|c|c|c|c|c|}
\hline & $\begin{array}{l}\text { Mal } \\
\mathrm{e}\end{array}$ & $\begin{array}{l}\text { Femal } \\
\mathrm{e}\end{array}$ & $\begin{array}{l}\text { Tota } \\
\text { I }\end{array}$ & $\begin{array}{l}\text { Minimu } \\
\mathrm{m}\end{array}$ & $\begin{array}{l}\text { Maximu } \\
\mathrm{m}\end{array}$ & $\begin{array}{l}\text { Mea } \\
\mathrm{n}\end{array}$ & SD \\
\hline Test anxiety & 81 & 108 & 189 & 24 & 69 & 45.43 & $\begin{array}{l}12.3 \\
4\end{array}$ \\
\hline $\begin{array}{l}\text { Communicatio } \\
\text { n apprehension }\end{array}$ & 81 & 108 & 189 & 11 & 55 & 32.30 & $\begin{array}{l}11.7 \\
7\end{array}$ \\
\hline $\begin{array}{c}\text { Fear of } \\
\text { negative } \\
\text { evaluation }\end{array}$ & 81 & 108 & 189 & 9 & 35 & 21.59 & $\begin{array}{l}7.69 \\
7\end{array}$ \\
\hline Total anxiety & 81 & 108 & 189 & 45 & 159 & 99.32 & $\begin{array}{l}30.6 \\
6\end{array}$ \\
\hline
\end{tabular}

\section{Results and discussion}

The purpose of the present study was to find out the sources of Iranian adult EFL learners' communication apprehension in the English classrooms. The FLCAS questionnaire was administered to the participants. A post-hoc interview was then conducted with the learners who were identified as the most anxious participants on the communication apprehension subscale of the questionnaire. Four themes emerged from the learners ' comments which were deemed as the most probable sources of speaking anxiety among the participants. The research findings obtained from the foreign language Classroom Anxiety Scale (FLCA) and semi-structure interview will be discussed in this section.

Research question: What are Iranian EFL learners' perceptions of the likely factors underpinning L2 communication apprehension speaking anxiety?

To answer the research question, the students who were identified to experience the highest level of communication apprehension were interviewed. The results of the interviews revealed that the participants all had negative feelings toward their English learning experience. Overall, the researchers came up with four sources of anxiety in the classroom context from the analysis of the interviews. A detailed discussion of these themes is presented below.

\section{Fear of English}

Learning a foreign language can be a demanding experience specifically for adult learners. They are mostly afraid of the face-threatening situation whether it is an exam or any other type of evaluation. To give sample comment: 
"I would rather avoid my English classes especially the days that we are supposed to be ready for a quiz".

Moreover, as $\mathrm{Na}$ (2007) claimed anxiety can make learners lose their motivation to learn and they may no longer believe in their abilities and escape from any kind of classroom activities and evaluation which may lead to their giving up effort to learn a foreign language.

Another student mentioned that English makes him so much anxiety that he is not able to concentrate.

"I've never been so anxious before, so I don't like attending these classes, no, I don't, it's so unpleasant; it doesn't feel good attending them."

A comment like this mostly has something to do with the classroom environment. Learners may find classroom context as highly anxiety provoking due to some factors mentioned earlier in literature like the formality of the environment, the presence of teachers and other students. Later in this section, we are going to talk more about that.

This finding is congruent with McCroskey (1983) pointing out that communication apprehension can be the result of many restrictions on passes on acceptable behavior in the language classroom. Fear of speaking English flawlessly not only can hinder students' performance. But also, it can lead to their discouragement in learning English. Krashen (1985) has discussed affective filter hypothesis in the theory of SLA. One of those effective filters that Krashen has mentioned is anxiety. He believed in order to let the comprehensible input get in, affective variables should be low. In other words, those learners who are suffering from Foreign Language Anxiety cannot acquire the second language. As it was mentioned in the comments, almost most of the highly anxious students felt uneasy during their class presence. This unpleasant experience might be due to the linguistic difficulty.

Students may find a linguistic and paralinguistic aspect of language learning difficult. This undeniable fact offers more studies should be undertaken regarding solutions, rather than only identification of the problem to enhance students' proficiency and lower their level of anxiety.

\section{Mistakes}

One of the big fears that the interviewees went through in their English classes was the concern they had over making mistakes.

One of them described her experience as "very tense" another student noted that he felt ashamed when he made a mistake. Based on comments this fear of mistake resulted from many different sources; learners themselves as the comment below:

"Whenever I make a mistake, I feel sorry for myself".

This finding is consistent with what Korpela (2011) mentioned in the internal causes of communication apprehension. As it was mentioned earlier in literature, Korpela relates students' level of perfectionism to their anxiety. Students avoid communication because to them it is essential to be flawless.

Being afraid of falling short of teacher's standards was also mentioned as fear of making mistakes: 
"What makes me anxious is that I know if I spoke English with some inaccurate structures and not as it is required by my teacher, it wouldn't be enough here, they expect more."

"When I want to satisfy my teacher's expectation, my anxiety even gets worse."

"When I speak English outside the classroom I don't pay so much attention to grammar and feel more relaxed, but here in class it's different, I don't dare to do the same".

"In the classroom, I am afraid of the way my teacher looks at me when I make a mistake."

This finding is congruent with Horwitz (2001) study indicating that teacher should be cognizant of the potential stressful situation caused by oral production.

Taking a glance at the studies previously cited, this study also found that students' feeling of embarrassment may be worsen by the role played by language instructors in the class (Horwitz et al., 1986; Price, 1991; Young, 1991; Young, 1990). The teachers' attitude towards learners' errors and the way they give their students feedback have been reported to be related to second/foreign language anxiety. Based on Junes (2004) the humiliating attitude of teachers toward their learners' mistake can be a hindrance in the learners' willingness to communicate.

In the classroom, however, anxious English learners found learning the target language as a laborious and very stressful experience, as they tried hard to remember all the rules of grammars to make their speech flawless.

\section{The teacher}

Being able to speak accurately and fluently was not the only stressful experience these high anxious selected participants went through. Teachers' personality type like teachers 'behavior and manner of correction students' mistake was found to be another cause of communication apprehension. Many of the interviewees thought that their failure to live up to their teachers' expectations and required standards was one of their biggest worries. They specifically pointed to the issue of being worried about losing credits unless they could satisfy their teachers' expectations.

"For me speaking English is dreadful, because of its consequences. I feel if I made so many mistakes, I would get worse grades."

This finding in accordance with Wörde (2003) states that teachers' personality can lead to foreign language anxiety. Manner and behavior of the teacher in the way she interacts with students can be a potential source of anxiety. Ehrman et al. (2003) claimed that teachers' negative feedback can be both source of learners' anxiety and losing their motivation and attention. Hsu's (2010) findings is also in congruent with this study indicating that teacher's personality can have an instant effect on learners' motivation

Besides the anxiety caused by the feeling of being evaluated by the teacher who is monitoring and testing their performance, some interviewees mentioned another teacher-related concern as their source of anxiety. This teacher-related source was the fear of being corrected in front of others To give a few examples:

"It's very embarrassing if a teacher corrects you in front of the whole class, you feel very 
uneasy, and even more so if they say things like "You should have known this age ago!",

"Even a secondary school pupil is supposed to know this"

In speaking, especially in lower proficiency levels, students do not find themselves confident enough to speak in front of the other students and in the presence of their teachers. Therefore, they naturally feel some apprehension while communicating in English. Teachers as one source of anxiety can intensify or relieve their students' anxiety level. Teachers' attempt to have learners talk without making errors results in their frequent interruption of their students to give them corrective feedback. Evidence for this comes from the highly anxious learners' comments in the interviews. As most of them noted the teacher can be a source of anxiety for them as he frequently looks for their errors while they are speaking and stops them to correct their mistakes. More specifically, speaking up in the classroom was anxiety-provoking for the participants not only because they were aware that their use of the TL was not always grammatical or error-free but also because they believed that failure to live up to expectations or meet the required standards of their teachers would affect their grades.

In effect, it can be concluded that in their attempt to fulfill their teachers' expectation for flawless speech, learners experience great pressure. These findings provide further support for Anderson`s (2015) study which showed perfectionist teachers make a lot of judgments about others and they expect people to be perfect and they are highly critical of those who fail to meet their standards, as a result they provoke anxiety for people whom they are dealing with.

As a matter of fact, teachers should get to know the discourse of world Englishes and the fact that we do not have one perfect form of English spoken by native speakers. Rather we have different Englishes, and that the goal of the L2 pedagogy must be equipping learners with the ability to make themselves understood in international settings and they should not put great pressure on learners to follow native speakers ' norms in all aspects of their $L 2$ use.

L2 teachers should become aware how their harsh reactions to their students' errors can make a classroom a site of fear of anxiety, cause error phobia in learners, and make language learning an unpleasant experience for learners as it was mentioned by learners participating in the interview section. Teachers should take students' self-confidence into account and not to shatter their students' self-efficacy which is defined by Brown (2001) as an essential factor which affects what a learner can achieve in learning a language.

\section{Classmates}

Another source of anxiety pointed by the interviewees was the negative remarks of their classmates on their performance, specifically their speaking. Some comments on this section are provided below:

"I'm more afraid of my classmates; I think they are intolerant of my mistakes".

"I always think that what my classmate would think of me if I say something wrong".

"I feel my classmates will look down on me if I make a mistake." 
International Conference on Research in

Humanities and Social Sciences

Serbia | Belgrade | December 15-17, 2018

"It's very important for me that my classmates don't think, more precisely don't find out, that I may know less."

Some of the students have mentioned their classmates as the source of their anxiety. It is undeniable that the concept of face plays a crucial role in collectivist culture. Interaction can be hindered if one of the interlocuters feels his control of language is imperfect and he may lose his face in front of others. This can be confirmed in the study which was done by Liu and Jackson (2008) who investigated willingness to communicate and anxiety of Chinese learners. The finding revealed that most of the students felt anxious to take part in conversations with their peers mostly because they were afraid of doing face threatening act due to their self-rated English proficiency. This finding is also in accord with Jones (2004) mentioning classmates as the origin of language anxiety.

The themes emerged from the comments of these highly anxious students were as follows (1) fear of Speaking English, (2) aiming at avoiding mistakes, (3) potential negative evaluation by the teacher (poor marks, being corrected, critical remarks), (4) potential negative evaluation by peers shows that they did not feel comfortable and at ease in their English classes.

\section{Conclusion}

This study was conducted to investigate the possible sources of EFL learners' speaking anxiety. To collect the related data for the hypothesis, the researcher utilized two instruments including foreign language classroom anxiety and interview. The result of the study revealed that Iranian EFL learners experience foreign language anxiety in their classroom specifically in their oral practices. As the themes emerged from the interview section of the study revealed the finding of this research is partially close to the recent study done by Korpela (2011) as mentioned earlier in literature he categorized the causes of anxiety into two subcategories of internal and external. Self-assessed level of students' proficiency and their unrealistic expectation from themselves to sound like a native speaker as one of the internal category is in congruent with the first and second theme emerged from this study, (1) fear of Speaking English and (2) aiming at avoiding mistakes, as external sources found in his study like high expectations of teachers and teacher's role in strengthening the learners fear to communicate and classroom context and the effect of peers have relation with the other themes of this study namely (3) potential negative evaluation by the teacher (poor marks, being corrected, critical remarks), (4) potential negative evaluation. This study aims to help both teachers and learners make an anxiety free atmosphere for a better learning to take place.

Regarding the findings of this study which documented causes of EFL learners' communication apprehension, experts in educational psychology can design some teacher training program to help teachers to set their standards in a way to create anxiety free atmosphere for their students. 


\section{References}

1. Alpert, R. \& Haber, R. N. (1960). Anxiety in academic achievement situations. Journal of Abnormal and Social Psychology, 61(2), 207-215.

2. Alrabai, F. (2015). The influence of teachers' anxiety-reducing strategies on learners' foreign language anxiety. Innovation in Language Learning and Teaching, 9(2), 163-190.

3. Anderson, J., (2015). Other-oriented Perfectionism Vs. Self-oriented Perfectionism; retrieved form http://reliawire.com/other-oriented-perfectionism-vs-self-oriented-perfectionism/

4. Atef-Vahid, S., \& Fard Kashani, A. (2011). The effect of English learning anxiety on Iranian highschool students' English language achievement. Brain. Broad Research in Artificial Intelligence and Neuroscience, 2(3), 29-44.

5. Baran-Lucarz, M. (2011). The Relationship between Language Anxiety and the Actual and Perceived Levels of Foreign Language Pronunciation. Studies in Second Language Learning and Teaching, 1(4), 491-514.

6. Bailey, P., Onwuegbuzie, A. J., \& Daley, C. E. (1999). Anxiety about foreign language students in French, Spanish, and German classes. Psychological Reports, 82, 1007-1010.

7. Brown, H. D. (2001). Teaching by principles: An interactive approach to language pedagogy. White Plains, NY: Pearson Education.

8. Bygate, M. (2009). Teaching the spoken foreign language. In K.Knapp \& B.Seilhofer (eds) Handbooks in applied linguistics, Vol.5: Foreign language communication and learning. Berlin: Mouton De Gruyter, pp.401-438.

9. Campbell, C. M. (1999). Language anxiety in men and women: Dealing with gender differences in the language classroom. In Dolly J. Young (Ed.), Affect in foreign language and second language learning: A practical guide to creating a low anxiety classroom atmosphere (pp.191215). Boston: McGraw-Hill College.

10. Conway J (2007). Anxiety in second language learning; Causes and solutions. EDU 380.

11. Dewaele, J. M. (2002). Psychological and sociodemographic correlates of communicative anxiety in L2 and L3 production. The International Journal of Bilingualism, 6(1), 23-28.

12. Dordinejad, GH. F., Hakimi, H., Ashouri, M., Dehghani, M., Zeinali, Zh., Sadegh, D. M., Bahrami, N., (2011). On the relationship between test anxiety and academic performance. Procedia Social and Behavioral Sciences, 15, 3474-3778.

13. Elkhafaifi, H. (2005). The effect of pre-listening activities on listening comprehension in Arabic learners. Foreign Language Annals, 38(4), 505-513.

14. Ellis, R. (2008). The Study of Second Language Acquisition. Oxford: Oxford University Press. 
International Conference on Research in

Humanities and Social Sciences

Serbia | Belgrade | December 15-17, 2018

15. Gardner, R. C., Day, J. B. \& MacIntyre. P. D. (1992). Integrative motivation, induced anxiety, and language learning in a controlled environment. Studies in Second Language Acquisition, 14, 197-214.

16. Gregersen, T. S., \& Horwitz, E. K. (2002). Language learning and perfectionism: Anxious and non-anxious language learners' reactions to their own oral performance. The Modern Language Journal, 86(4), 562-570.

17. Gregersen, T. S. (2003). To Err Is Human: A Reminder to Teachers of Language-Anxious Students. Foreign Language Annals, 36(1)

18. Hashemi M., Abbasi M. (2013). The role of the teacher in alleviating anxiety in language classes. International Journal of Applied and Basic Sciences. Science Explore Publications, 4 (3), 2251-838X.

19. Horwitz, E. K. (1986). Preliminary evidence for the reliability and validity of a Foreign Language Anxiety Scale. TESOL Quarterly, 20, 559-562.

20. Horwitz, E. K., Horwitz, M. B., and Cope, J. (1986) Foreign Language Classroom Anxiety. The Modern Language Journal, 70(2): 125- 132.

21. Horwitz, E. K., \& Young, D. J. (1991). Language anxiety: From theory and research to classroom implications. Upper Saddle River, NJ: Prentice Hall.Horwitz, E. K. (1990). Attending to the affective domain in the foreign language classroom. In S. Magnan (Ed.), 1990 Reports of the Northeast Conference of Foreign Language Teachers (pp. 15-31). Lincolnwood, IL: National Textbook Company

22. Horwitz, E. K. (2001). Language anxiety and achievement. Annual Review of Applied Linguistics, 21, 112-126.

23. Horwitz, E. K. (2010). Foreign and second language anxiety. Language Teaching, 43(2), 154167

24. Hsu, L. (2010) The Impact of Perceived Teachers' Nonverbal Immediacy on Students' Motivation for Learning English. Online Asian EFL Journal, 12(4): 188-204.

25. Jones JF (2004). A cultural context for language anxiety. EA (English Australia) J. 21(2):30-39

26. Kitano, K. (2001) Anxiety in the College Japanese Language Classroom. The ModernLanguage Journal, 85(4): 549-566.

27. Korpela, L. (2011). Why don't students talk? Causes of foreign language communication apprehension in English classes: a comparison of high apprehensive and low apprehensive upper secondary students. Unpublished M.A. thesis. University of Helsinki: Department of Teacher Education.

28. Krashen, S.D. (1985). The input hypothesis: Issues and implications. Torrance, CA: Loredo

29. Publishing 
International Conference on Research in

Humanities and Social Sciences

Serbia | Belgrade | December 15-17, 2018

30. Kremenitzer, J.P. (2005). The emotionally intelligent early childhood educator: self-reflective journaling. Early Childhood Education Journal, 33 (1), 3-9

31. Lev-Ari, S., \& Keysar, B. (2010). Why don't we believe non-native speakers? The influence of accent on credibility. Journal of Experimental Social Psychology, 46(6), 1093-1096.

32. Liu, M. \& Jackson, J. (2008) An Exploration of Chinese EFL Learners' Unwillingness to

33. Communicate and Foreign Language Anxiety.The Modern Language Journal, 92.

34. Luo, H. (2012). Sources of Foreign Language Anxiety: Towards a Four-dimension Model. Contemporary Foreign Language Studies, 12, 49-61.

35. Maclntyre, P. D., \& Gardner, R. C. (1989). Anxiety and second language learning: Toward a theoretical clarification. Language Learning, 39(2), 251-275.

36. MacIntyre, P. D., \& Gardner, R. C. (1991). Methods and results in the study of anxiety in language learning: A review of the literature. Language Learning, 41, 85-117.

37. Maclntyre P. D. Gardner, R. C., (1993). A student's contribution to second language learning: Part II. Affective variables. Language Teaching, 26, 1-11.

38. McCroskey, J.C. (1983). The communication apprehension perspective. Communication, 12(1), 1-25.

39. McCroskey, J.C. and Richmond, V.P. (1995) Communication: apprehension, avoidance and

40. effectiveness. 4th ed. Scottsdale, AZ: Gorsuch Scarisbrick.

41. Na Z (2007). A study of high school students" English learning anxiety. Asian EFL J. 9(3):2234.

42. Oh, J. (1992). The effects of L2 reading assessment methods on anxiety level. TESOL Quarterly, 26(1), 172-176.

43. Onwuegbuzie, A, J., Bailey, P., \& Daley, C, E. (1999) „Factors Associated With Foreign Language Anxiety”, Applied Psycholinguistics, Vol. 20 (2), 217-239 Peirce, B. N. (1995) „Social Identity, Investment, and Language Learning", TESOL Quarterly, Vol. 29(1), pp. 9-31

44. Oxford, R. (1999a). Anxiety and the language learner: New insights (pp. 58-67). In J. Arnold (Ed.), Affect in Language Learning. Cambridge, UK: Cambridge University Press.

45. Oxford, R. L. (2005) Anxiety and the Language Learner: New Insights. In Affect in language learning, edited by J. Arnold, pp. 58-67. Cambridge: Cambridge University Press

46. Phillips, E. M. (1992). "The effects of language anxiety on students' oral-test performance and attitudes". Modern Language Journal. 76(1), 14-26.

47. Powell, R., (1991). In the Pursuit of Power and Plenty. University of California, Berkeley. Typescript. 
48. Price, M. L. (1991). The subjective experience of foreign language anxiety: Interviews with highly anxious students. In E. K. Horwitz \& D. J. Young (Eds.), Language anxiety: From theory and research to classroom implications (pp. 101-108). New Jersey: Prentice Hall Inc.

49. Rajanthran S, Prakash R, Husin A (2013). Anxiety levels of foreign language learners in the IEP classroom: A Focus on Nilai University's intensive English programme (IEP). Int. J. Asian Soc. Sci. 3(9):2041-2051.

50. Saito, Y., \& Samimy, K. (1996). Foreign language anxiety and language performance: A study of learner anxiety in beginning, intermediate, and advanced-level college students of Japanese. Foreign Language Annals, 29, 239-251.

51. Samimy, K. K. (1989). A comparative study of teaching Japanese in the audio-lingual method and the counseling-learning approach. The Modern Language Journal, 73(2), 169-177.

52. Scovel, T. (1978). The effect of affect in foreign language learning: A review of the anxiety research. Language Learning, 28(1), 129142.

53. Sellers, V. D. (2000). Anxiety and reading comprehension in Spanish as a foreign language. Foreign Language Annals, 33(5), 512.

54. Sparks, R. L., \& Ganschow, L. (1991). Foreign language learning differences: Affective or native language aptitude. Modern Language Journal, 75(1), 216-463.

55. Sparks, R. L., \& Ganschow, L. (1993a). The impact of native language learning problems on foreign language learning: Case study illustrations of the linguistic coding deficit hypothesis. Modern Language Journal, 77(1), 58-74.

56. Sparks, R. L., \& Ganschow, L. (1993b). Searching for the cognitive locus of foreign language learning difficulties: Linking first and second language learning. Modern Language Journal, 77(3), 289-302.

57. Spielberger, C. D. (1983). Manual for the state-trait anxiety inventory (Form Y). Palo Altom CA: Psychological Press.

58. Spielmann, G., \& Radnofsky, M. L. (2001). Learning language under tension: New directions from a qualitative study. The Modern Language Journal, 85(2), 259-278. http://dx.doi.org/10.1111/0026-7902.00108

59. Tallon, M. (2006). Foreign language anxiety in heritage students of Spanish: To be (anxious) or not to be (anxious)? That is the question. (Unpublished doctoral dissertation). University of Texas at Austin, Austin, TX.

60. Terampi, A. S., Lambert, W. E., \& Tucker, G.R. (1968). Audience sensitivity and oral skill in a second language. Philippine Journal for Language Teaching, 6, 27-33.

61. Wörde, R. (2003) Students' Perception on Foreign Language Anxiety. Inquiry, 8(1). [Online URL: http://www.vccaedu.org/inquiry/ inquiry-spring2003/i-81-Wörde.html] accessed on October 1, 
International Conference on Research in

Humanities and Social Sciences

Serbia | Belgrade | December 15-17, 2018

62. Yan, J. X., \& Horwitz, E. K. (2008). Learners' perceptions of how anxiety interacts with personal and instructional factors to infl uence their achievement in English: A qualitative analysis of EFL learners in China. Language Learning, 58(1), 151-183.

63. Young, D. J. (1990). An investigation of students' perspectives on anxiety and speaking. Foreign

64. Language Annals, 23(6), 539-553. https://doi.org/10.1111/j.1944-9720.1990.tb00424.x

65. Young, D. J. (1991). Creating a low-anxiety classroom environment: What does the language anxiety research suggest? Modern Language Journal, 75(4), 426-437.

66. Young, D. J. (1994). New directions in language anxiety research. In Klee, C. A. (Ed.), Faces in a crowd: The individual learner in multisection courses (pp. 3-46). Boston, MA: Heinle \& Heinle.

67. Young, D. J. (1999). Affect in foreign language and second language learning: A practical guide to creating a low-anxiety classroom atmosphere. Boston, MA: McGraw-Hill College.

68. Zhang R, Zhong J (2012). The hindrance of doubt: Causes of language anxiety. Int. J. English Linguist. 2(3):27-33. doi:10.5539/ijel.v2n3p27

69. Zheng, Y. (2008). Anxiety and second/foreign language learning revisited. CJNSE/RCJCÉ, 1(1). 
International Conference on Research in

Humanities and Social Sciences

Serbia | Belgrade | December 15-17, 2018

\section{APPENDIX A: Foreign language Classroom Anxiety Scale \\ Foreign Language Classroom Anxiety Scale}

Horwitz, E. K., Horwitz, M. B., \& Cope, J. (1986). Foreign language classroom anxiety. The Modern Language Journal, 70(2), 125-132.

1. I never feel quite sure of myself when I am speaking in my foreign language class.
Strongly agree
Agree
Neither agree nor disagree
Disagree

Strongly disagree

2. I don't worry about making mistakes in language class.

Strongly agree

Agree

Neither agree nor disagree

Disagree

Strongly disagree

3. I tremble when I know that I'm going to be called on in language class.

Strongly agree

Agree

Neither agree nor disagree

Disagree

Strongly disagree

4. It frightens me when I don't understand what the teacher is saying in the foreign language.

Strongly agree

Agree

Neither agree nor disagree

Disagree

Strongly disagree

5. It wouldn't bother me at all to take more foreign language classes. 


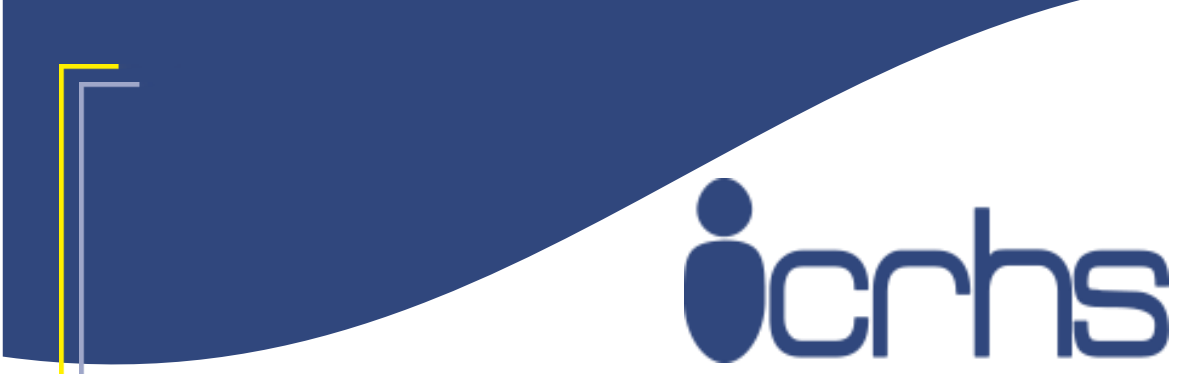

International Conference on Research in

Humanities and Social Sciences

Serbia | Belgrade | December 15-17, 2018

Strongly agree

Agree

Neither agree nor disagree

Disagree

Strongly disagree

6. During language class, I find myself thinking about things that have nothing to do with the course.

Strongly agree

Agree

Neither agree nor disagree

Disagree

Strongly disagree

7. I keep thinking that the other students are better at languages than I am.

Strongly agree

Agree

Neither agree nor disagree

Disagree

Strongly disagree

8. I am usually at ease during tests in my language class.

Strongly agree

Agree

Neither agree nor disagree

Disagree

Strongly disagree

9. I start to panic when I have to speak without preparation in language class.

Strongly agree

Agree

Neither agree nor disagree

Disagree

Strongly disagree

10. I worry about the consequences of failing my foreign language class.

Strongly agree

Agree

Neither agree nor disagree

Disagree

Strongly disagree

11. I don't understand why some people get so upset over foreign language classes. 


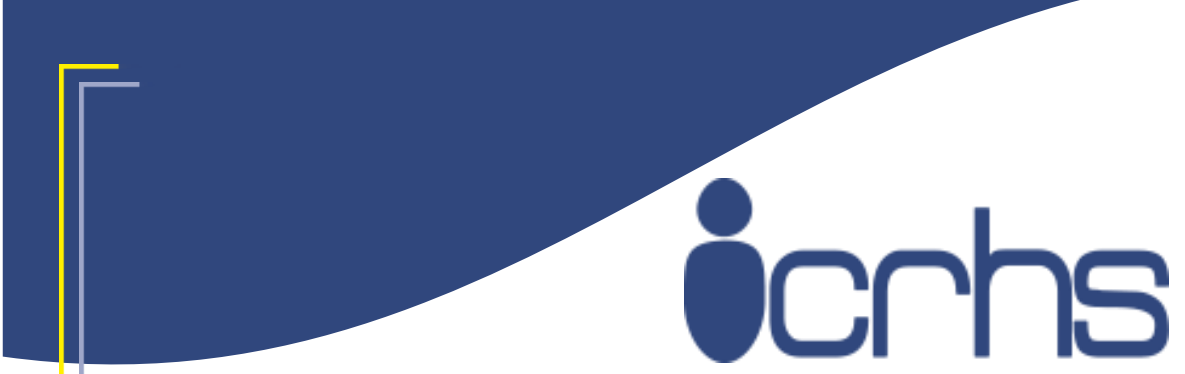

International Conference on Research in

Humanities and Social Sciences

Serbia | Belgrade | December 15-17, 2018

Strongly agree

Agree

Neither agree nor disagree

Disagree

Strongly disagree

12. In language class, I can get so nervous I forget things I know.

Strongly agree

Agree

Neither agree nor disagree

Disagree

Strongly disagree

13. It embarrasses me to volunteer answers in my language class.

Strongly agree

Agree

Neither agree nor disagree

Disagree

Strongly disagree

14. I would not be nervous speaking the foreign language with native speakers.

Strongly agree

Agree

Neither agree nor disagree

Disagree

Strongly disagree

15. I get upset when I don't understand what the teacher is correcting.

Strongly agree

Agree

Neither agree nor disagree

Disagree

Strongly disagree

16. Even if I am well prepared for language class, I feel anxious about it.

Strongly agree

Agree

Neither agree nor disagree

Disagree

Strongly disagree

17. I often feel like not going to my language class. 


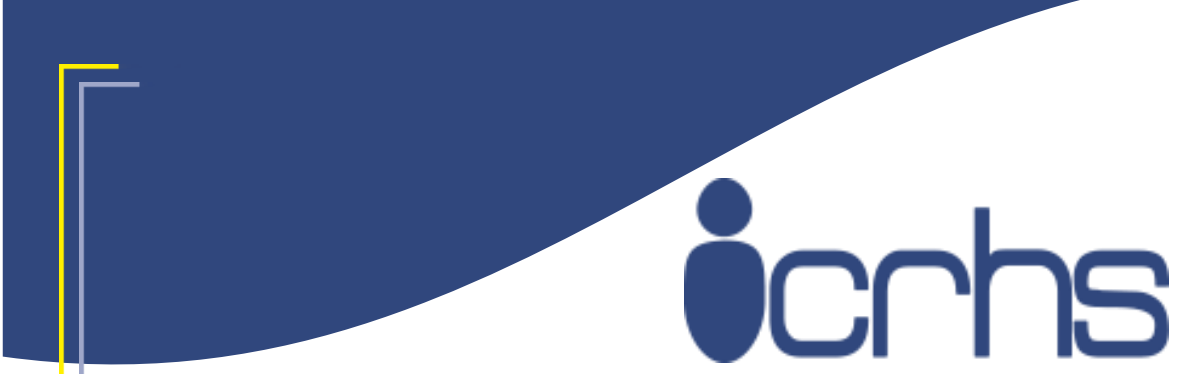

International Conference on Research in

Humanities and Social Sciences

Serbia | Belgrade | December 15-17, 2018

Strongly agree

Agree

Neither agree nor disagree

Disagree

Strongly disagree

18. I feel confident when I speak in foreign language class.

Strongly agree

Agree

Neither agree nor disagree

Disagree

Strongly disagree

19. I am afraid that my language teacher is ready to correct every mistake I make.
Strongly agree
Agree
Neither agree nor disagree
Disagree

Strongly disagree

20. I can feel my heart pounding when I'm going to be called on in language class.
Strongly agree
Agree
Neither agree nor disagree
Disagree

Strongly disagree

21. The more I study for a language test, the more confused I get.

Strongly agree

Agree

Neither agree nor disagree

Disagree

Strongly disagree

22. I don't feel pressure to prepare very well for language class.

Strongly agree

Agree

Neither agree nor disagree

Disagree

Strongly disagree

23. I always feel that the other students speak the foreign language better than I do. 


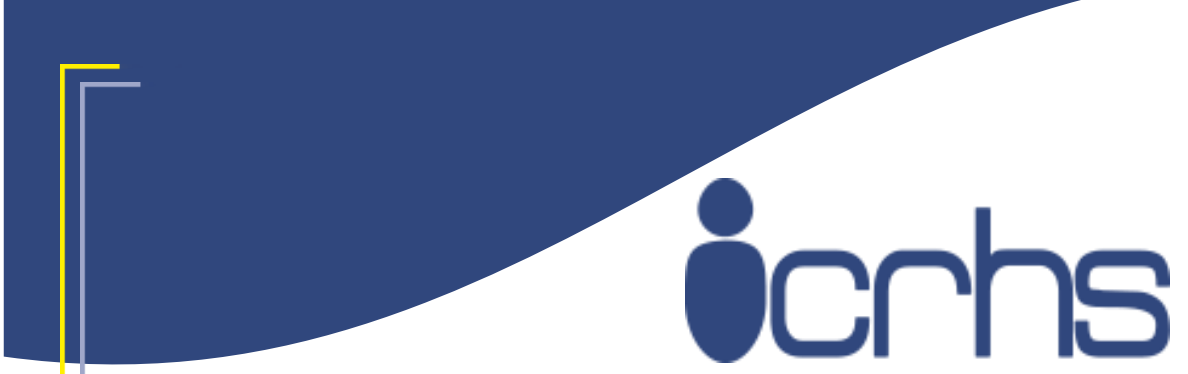

International Conference on Research in

Humanities and Social Sciences

Serbia | Belgrade | December 15-17, 2018

Strongly agree

Agree

Neither agree nor disagree

Disagree

Strongly disagree

24. I feel very self-conscious about speaking the foreign language in front of other students.

Strongly agree

Agree

Neither agree nor disagree

Disagree

Strongly disagree

25. Language class moves so quickly I worry about getting left behind.

Strongly agree

Agree

Neither agree nor disagree

Disagree

Strongly disagree

26. I feel more tense and nervous in my language class than in my other classes.

Strongly agree

Agree

Neither agree nor disagree

Disagree

Strongly disagree

27. I get nervous and confused when I am speaking in my language class.

Strongly agree

Agree

Neither agree nor disagree

Disagree

Strongly disagree

28. When I'm on my way to language class, I feel very sure and relaxed.

Strongly agree

Agree

Neither agree nor disagree

Disagree

Strongly disagree

29. I get nervous when I don't understand every word the language teacher says. 
International Conference on Research in

Humanities and Social Sciences

Serbia | Belgrade | December 15-17, 2018

Strongly agree

Agree

Neither agree nor disagree

Disagree

Strongly disagree

30. I feel overwhelmed by the number of rules you have to learn to speak a foreign language.

Strongly agree

Agree

Neither agree nor disagree

Disagree

Strongly disagree

31. I am afraid that the other students will laugh at me when I speak the foreign language.

Strongly agree

Agree

Neither agree nor disagree

Disagree

Strongly disagree

32. I would probably feel comfortable around native speakers of the foreign language.

Strongly agree

Agree

Neither agree nor disagree

Disagree

Strongly disagree

33. I get nervous when the language teacher asks questions which I haven't prepared in advance.

Strongly agree

Agree

Neither agree nor disagree

Disagree

Strongly disagree 
International Conference on Research in

Humanities and Social Sciences

Serbia | Belgrade | December 15-17, 2018

\section{APPENDIX B: Translated version of FLCAS}

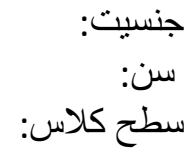

\begin{tabular}{|c|c|c|c|c|c|c|}
\hline مخالفم & مخالفم & 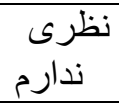 & مو افقم & ش مويدا & سو الات & رديف \\
\hline & & & & & 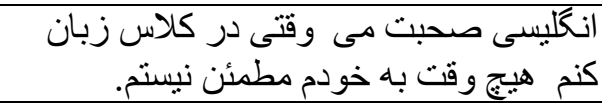 & 1 \\
\hline & & & & & نيستم. كلاس زبان انكليسى نكر ان اشتباه كردن & 2 \\
\hline & & & & & 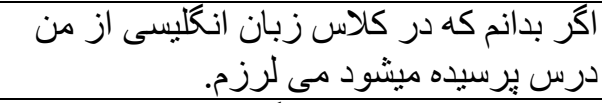 & 3 \\
\hline & & & & & 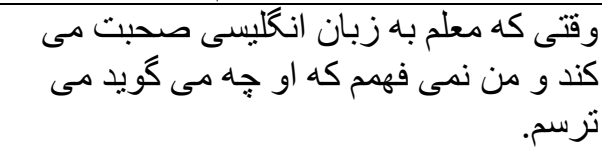 & 4 \\
\hline & & & & & 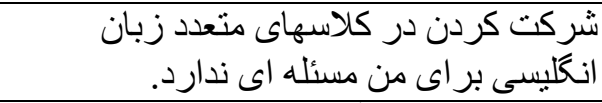 & 5 \\
\hline & & & & & 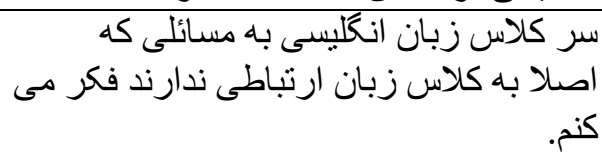 & 6 \\
\hline & & & & & دادكئم فكر ميكان انكليسى دانش بهتر آموز من ديكر در. & 7 \\
\hline & & & & & هنخام امتحان زبان انكليسى معمو لا در & 8 \\
\hline & & & & & 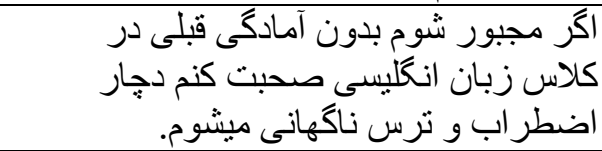 & 9 \\
\hline & & & & & انكليسى هيامد مردود شدن در كلاس زبان & 10 \\
\hline
\end{tabular}


International Conference on Research in

Humanities and Social Sciences

Serbia | Belgrade | December 15-17, 2018

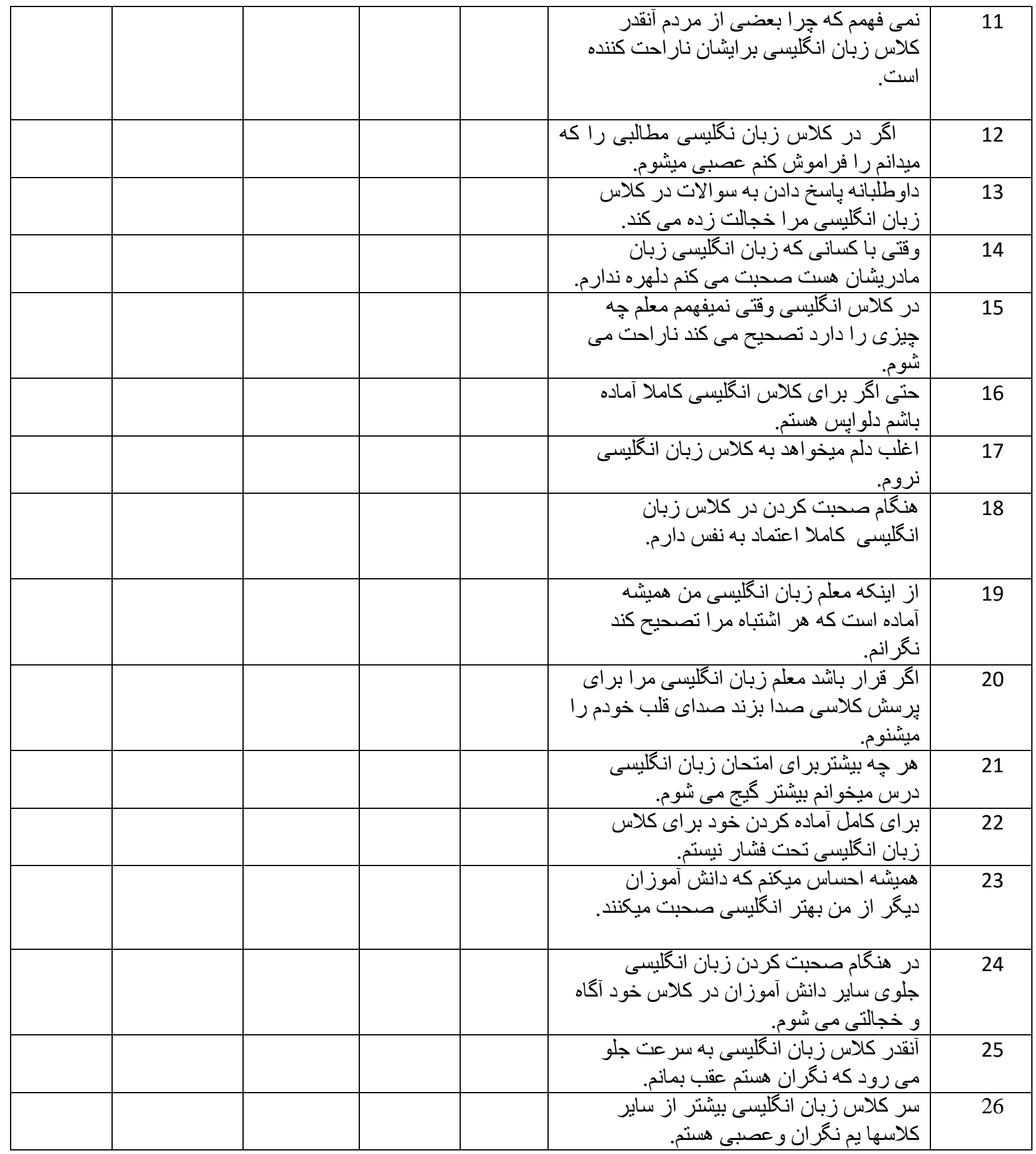


International Conference on Research in

Humanities and Social Sciences

Serbia | Belgrade | December 15-17, 2018

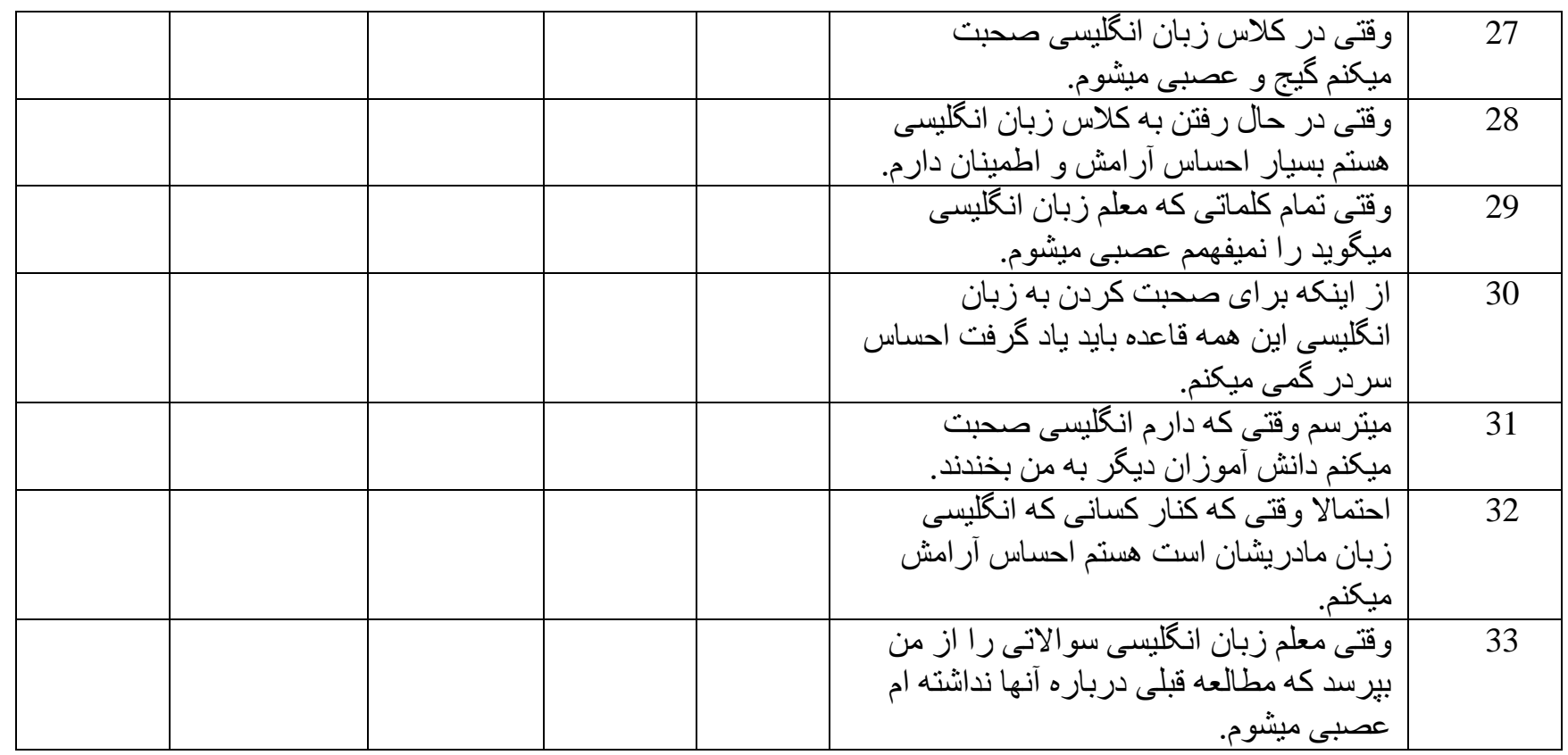

\section{APPENDIX C: Interview Questions}

1. How long have you been studying English?

2. How do you feel about learning English?

3. What do you like and dislike about learning English?

4. Do you feel anxious while learning? Why? Why not?

5. Do you feel anxious while using English? Why? Why not?

6. Under what circumstances do you feel anxious while learning English? Could you give an example? What factors do you think makes you anxious under these circumstances?

7. Under what circumstances do you feel anxious about your performance in English? Could you give an example? What factors do you think makes you anxious under these circumstances? 
International Conference on Research in Humanities and Social Sciences Serbia | Belgrade | December 15-17, 2018

8. Tell me how do you exactly feel when you are nervous in terms of your physical and mental symptoms?

9. Do you feel anxious while speaking your L1? Why? Why not?

10. To what extent do you think your propensity to become anxious while speaking in L1 might cause you being anxious while speaking in L2?

11. Do you think that anxiety-provoking situations in L1 can differ from those in L2?

12. What factors do you believe can help reduce your anxiety while speaking in English? 